coast, near Jaffa. So far as known to us, no Platyetenean has up to now been described from the Mediterranean. Therefore we presume that we are dealing with the Red Sea form (Coeloplana Metschnikowii Kowalewsky, 1880) or else with a new species. If our specimens should belong to the Red Sea species, this would mean that this interesting animal-like many others-has succeeded in penetrating through the Suez Canal into the eastern Mediterranean.

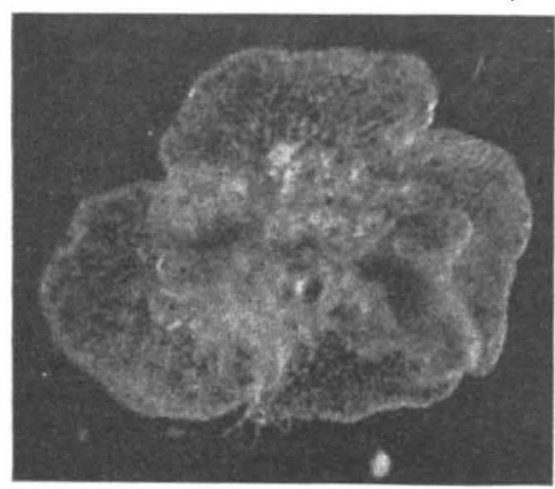

A preliminary examination tends to confirm this diagnosis of the genus Coloplana : the animal apposirs to be devoid of comb-plates but possesses the characteristic aboral papillæ of Cœloplana. The animals are $12-13 \mathrm{~mm}$. long and $9 \mathrm{~mm}$. broad, and they were observed both creeping on the substrate and hanging on the water surface. One specimen swallowed an Isopod of $2 \mathrm{~mm}$. length. The tentacles can be extended more than $15 \mathrm{~cm}$. The accompanying photograph, taken by Dr. W. Koch, shows a specimen with one tentacle partly extended.

Department of Zoology,

Hebrew University,

J. HaAs.

Jerusalem.

Nov. 12.

\section{Northern Fringe of the Palæolithic in England}

THE question as to whether the northern fringe of the Palæolithic in England extended into Yorkshire or not has long been a matter of controversy. Certain archæologists have supported such an extension on the ground that many palæolithic typos of implement have been discovered there, while most geologists have denied it on the ground that climatic conditions would have rendered any human pэnotration of Yorkshire impossible throughout the Ice Age.

For a thesis recently accepted by the University of Durham I have made a close investigation of this problem, re-examining both the implements discovered and the details of their discovery.

The investigation has revealed that many of the implements are undoubted palmoliths, but do not belong to any of the earlier Palaolithic cultures, being, with the possible exception of one group from Niddordale, Dabased Creswellian. At two sites at least, one in the Huddersfield region and the other near Settle, these palæoliths were certainly deposited prior to the earliest apparance of Mesolithic influences. The strata in which these palæoliths occur, in all cases where they can be identified. are postglacial in date. The Palieolithic sites, almost without excention, are situated on elevated ground, the majority on the Pennine Ridge, a few on the Yorkshire Moors and Yorkshire Wolds. The genuine palæoliths are few in number compared with the implements of later cultures; a few of the stone implements are of flint and comparatively woll made, but the majority are of chert and exceedingly crude. As a goneral rule the better-made implements are the earlier, the more crude the later, though the latter tend to improve slightly as the period draws to a close.

These facts make it clear that there was a Palæo. lithic period in Yorkshire, but that this period was post-glacial, not interglacial, in date. Thus the opposed views of the geologists and the archæologists can be largely reconciled.

It is possible to reconstruct in broad outline the sequence of events which hrought about the abovementioned conditions. The Creswellian Culture is known to have persisted in Derbyshire and Lincolnshire long after the contemporary palæolithic cultures on the Continent and even in southern England had been. superseded by the Mesolithic ${ }^{1}$. During this period the ice withdrew from the greater part of Yorkshire, and immediately small hunting parties began to enter that county, keeping to the elevated ground, as the valleys and plains would still be impassable.

At first these parties would be mere seasonal visitors, returning to the Derbyshire and Lincoln. shire centres for the winter; but as conditions improved, some at least settled in Yorkshire, living the life of nomadic hunters. The original migrants would take with them flint tools and weapons manufactured by skilled workmen at the North Midland sites, thus accounting for the comparatively wellmade implements; but their descendants would have to improvise with the somewhat intractable local chert, which explains the deterioration of the workmanship.

There appears to have been a break in these migrations, during which mesolithic influences reached the Derbyshire and Lincolnshire sites, and when conditions further improved and a general advance northward was made, it was by a people in a mesolithic stage. The descendants of the earlier migrants were then either absorbed or became extinct.

It is hoped at som 9 future date to publish full details of the evidence on which these conclusions are based, as well as a disctussion of several subsidiary questions arising out of the main problem.

120 Shipley Fields Road, H. N. Grbson. Frizinghall, Bradford,

Yorks.

Dec. 27.

1 Clark, J. G. D., "The Mesolithte Settlement of Northern Europe" 220 (Ċambridge, 1936).

\section{Names of Electrical Units}

Ir the E.S.U. system is to be retained, Dr. E. A. Guggenheim's suggestion ${ }^{1}$ that the unit of electrical charge in this system should be called the "franklin" has much to commend it. But why retain the E.S.U. system ? The object of the M.K.s. system is to replace three existing ones, with their cumbersome conversion factors, by one single system which meets all practical requirements.

It is unsound to give an arbitrary unit value to more physical quantities than necessary, though the practice is sometimes unavoidable (we can, for ex- 